\title{
Specific lytic activity against mycobacterial antigens is inversely correlated with the severity of tuberculosis
}

\author{
S. S. DE LA BARRERA*, M. FINIASZ², A. FRIAS*, M. ALEMÁN*, P. BARRIONUEVO*, S. FINK*, M. C. FRANCO†, \\ E. ABBATE \& M. DEL C. SASIAIN**Departamento de Inmunología, Instituto de Investigaciones Hematológicas (IIHema), \\ Academia Nacional de Medicina, and †Instituto Vaccarezza - Hospital F.J.Muñiz, Buenos Aires, Argentina
}

(Accepted for publication 3 April 2003)

\begin{abstract}
SUMMARY
The ability of peripheral blood mononuclear cells (PBMC) from patients with active tuberculosis to display cytotoxic responses against autologous Mycobacterium tuberculosis (Mtb)-pulsed macrophages was evaluated. Non-MHC restricted cell-dependent lytic activity was observed in ex vivo effector cells from tuberculosis patients and was mediated mainly by $\mathrm{CD}^{+} \gamma \delta \mathrm{TCR}^{+} \mathrm{T}(\gamma \delta \mathrm{T})$ cells bearing CD56 and/ or CD16 molecules. MHC-restricted and non-MHC restricted cytotoxic T cells (CTL) were differentially expanded upon stimulation with $M t b$ in tuberculosis patients and normal controls (N). Class-I restricted $\mathrm{CD} 8^{+} \mathrm{CTL}$ and class-II restricted $\mathrm{CD} 4^{+} \mathrm{CTL}$ were generated in $\mathrm{PPD}^{+} \mathrm{N}$ and to a lesser extent in $\mathrm{PPD}^{-} \mathrm{N} . M t b$-stimulated effector cells from tuberculosis patients became progressively non-MHC restricted $\mathrm{CD} 4^{-} \mathrm{CD} 8^{-} \gamma \delta \mathrm{T}$ cells, while lytic activity of $\mathrm{CD} 4^{+}$and $\mathrm{CD} 8^{+} \mathrm{CTL}$ decreased gradually as the disease became more severe. On the other hand, target cells were lysed by ex vivo cells from tuberculosis patients through the Fas-FasL and perforin pathways. $M t b$-induced CD4 ${ }^{+}$CTL from tuberculosis patients and $\mathrm{N}$ controls preferentially employed the Fas-FasL mechanism. $M t b$-induced $\mathrm{CD} 8^{+} \mathrm{CTL}$ effector cells from patients used the perforin-based mechanism while cells from $\mathrm{N}$ controls also used the Fas-FasL pathway. While $M t b$-induced $\gamma \delta$ CTL from patients and PPD $^{-} \mathrm{N}$ employed the latter mechanism cells from $\mathrm{PPD}^{+} \mathrm{N}$ individuals also used the perforin pathway. It can be concluded that shifts in the CTL response and the cytolytic mechanisms take place as the pulmonary involvement becomes more severe.
\end{abstract}

Keywords cytotoxicity lymphocytes tuberculosis

\section{INTRODUCTION}

Mycobacterium tuberculosis (Mtb), the aetiological agent of tuberculosis, is an intracellular pathogen that resides and replicates within macrophages. Most healthy individuals infected with $M t b$ have the ability to control the infection by mounting an immune response capable of arresting the growth of bacilli within the granuloma. It was thought initially that antigen-specific $\mathrm{CD}^{+}$ $\mathrm{T}$ lymphocytes were the main effector cells of protective responses against $M t b$. However, there is increasing evidence that lysis of infected cells and killing of the invading pathogen also contribute to immune protection against $M t b[1]$. CD $4^{+} \mathrm{T}$ cells participate in the control of $M t b$ infection not only through the

Correspondence: Dr María del Carmen Sasiain, IIHema, Inmunología, Academia Nacional de Medicina, Pacheco de Melo 3081,1425 Buenos Aires, Argentina.

E-mail: msasiain@hematologia.anm.edu.ar production of type 1 cytokines, but also by their ability to lyse mycobacteria-infected and mycobacterial antigen-pulsed macrophages [2,3]. Although the role of $\mathrm{CD}^{+} \mathrm{T}$ cells in human tuberculosis remains controversial, their participation as cytotoxic $\mathrm{T}$ lymphocytes (CTL) is supported by studies in both murine and human tuberculosis, where $M t b$-specific $\mathrm{CD}^{+} \mathrm{CTL}$ have been isolated [4-7]. A role for $\gamma \delta \mathrm{T}$ cells in the protection of normal healthy individuals against tuberculosis has been established by their in vitro proliferation in response to antigenic preparations of $M t b[8,9]$. Despite differences in the antigens recognized and cytokine production, it has been demonstrated in healthy purified protein derivative positive $\left(\mathrm{PPD}^{+}\right)$individuals, that $\mathrm{CD}^{+}$and $\gamma \delta \mathrm{T}$ cells have similar effector functions such as cytotoxicity and interferon-gamma (IFN- $\gamma$ ) production [10]. $\mathrm{CD}^{+}$and $\mathrm{CD}^{+} \mathrm{T}$ cells recognize mycobacterial peptides in the context of major histocompatibilty complex (MHC) class-II and class-I proteins, respectively $[10,11]$ while $C D 3^{+} \gamma \delta$ T cells recognize small peptides as well as phosphate containing antigens $[12,13]$ in a non-MHC 
restricted manner. The family of CD1 surface molecules (CD1a, $\mathrm{CD} 1 \mathrm{~b}, \mathrm{CD} 1 \mathrm{c})$ react with double-negative, $\mathrm{CD} 8^{+}$or $\gamma \delta \mathrm{T}$ cells and have a high structural and conformational homology to MHC class-I molecules [14-16]. Moreover, CD1 has been shown to mediate specific T-cell recognition of non-peptide forms of mycobacterial cell wall constituents by which mycobacteria-infected macrophages can be lysed [14-16].

Two major mechanisms of lysis are recognized, exocytosis of cytotoxic granules, containing pore-forming perforin and serine esterase granzyme molecules and induction of apoptosis by ligation of CD95 (Fas) with CD95 ligand (CD95L, FasL) [17]. Expression of both perforin and CD95L has been demonstrated in PPDspecific $\mathrm{CD}^{+} \mathrm{T}$ cell clones [18]. In addition, $M t b$-reactive $\mathrm{CD}^{+}$ and $\mathrm{CD}^{+} \mathrm{T}$ cell lines from $\mathrm{PPD}^{+}$healthy individuals, lysed $\mathrm{Mtb}$ infected monocytes through perforin and Fas/FasL-dependent mechanisms [19]. It has also been reported that $\mathrm{CD} 8^{+} \mathrm{T}$ cells lyse and kill the mycobacterium inside $M t b$-infected cells by the release of granulysin and perforin [20,21]. As $\gamma \delta$ T cells possess cytolytic granules and express FasL [22], the lysis could be mediated by both pathways [23,24].

In this study we evaluated the ability of peripheral blood mononuclear cells (PBMC) freshly isolated from tuberculosis patients and PBMC cultured in the presence of $M t b$ (CTL), with or without previous pulmonary tuberculosis, to develop cytotoxic responses against autologous macrophages presenting $M t b$ antigens. In addition, we analysed the nature of the effector cells involved in the cytotoxic response as well as the lytic mechanisms employed by recently isolated and $M t b$-induced CTL to lyse $M t b$ pulsed macrophages from tuberculosis patients and healthy individuals. We demonstrate that in tuberculosis patients the in vivo activation of circulating $\mathrm{CD}^{+} \gamma \delta \mathrm{T}$ cells that bear the CD56 and/ or CD16 antigen are the main cytotoxic cells involved in the nonMHC restricted lysis of $M t b$-pulsed macrophages. Upon in vitro stimulation of PBMC with $M t b$ a loss of $\mathrm{CD}^{+}$and $\mathrm{CD} 8^{+} \mathrm{CTL}$ with an increase in $\mathrm{CD}^{-}{ }^{-} \mathrm{CD} 8^{-} \gamma \delta \mathrm{CTL}$ are observed and can be associated with the severity of pulmonary involvement. Moreover, the lytic mechanisms used by the different subsets of cytotoxic T cell to lyse target cells differ between patients and healthy PPD ${ }^{+}$ individuals.

\section{METHODS}

\section{Patients}

A total of 51 patients with pulmonary tuberculosis were studied. Patients were diagnosed by the presence of recent clinical symptoms of tuberculosis, a positive sputum smear test for acid-fast bacilli confirmed by a positive culture of tuberculosis bacilli and abnormal chest radiography. Informed consent was obtained from patients according to the Ethics Commission of the Hospital Francisco J. Muñiz and of IIHema, Academia Nacional de Medicina. All patients had active tuberculosis and were under multidrug treatment at the time of study (2-45 days). Pulmonary disease was classified according to the extent and type of X-ray findings into mild (M) and advanced (A) tuberculosis according to the American Tuberculosis Society criteria. Of the patients, 18 had M and 33 had A tuberculosis. Patients positive for HIV (human immunodeficiency virus) or other concurrent infectious diseases were excluded. They were classified into two groups: (a) patients without previous pulmonary tuberculosis $=\mathrm{TB}-$ these include patients with M-TB $(n=9$, eight men and one woman, 1955 years) and with A-TB ( $n=15,13$ men and two women, 22-
68 years); and (b) patients with pulmonary tuberculosis overcome at least 3 years earlier with posterior reactivation of the disease $=$ pre-TB - these were also separated in M-pre-TB $(n=9$, seven men and two women, 20-45 years) and A-pre-TB ( $n=18,14$ men and four women, 25-65 years). The controls included 16 healthy individuals $(\mathrm{N})$ (10 men, six women, 25-60 years, eight tuberculin reactive $\left(\mathrm{PPD}^{+}\right)$and $\left.8 \mathrm{PPD}^{-}\right)$.

\section{Mononuclear cells}

PBMC were isolated from heparinized blood by FicollHypaque gradient centrifugation [25] and then resuspended in tissue culture medium (GIBCO Laboratory, NY, USA) containing gentamycin $(85 \mu \mathrm{g} / \mathrm{ml})$ and $15 \%$ heat-inactivated fetal calf serum (FCS) (GIBCO Laboratory, NY, USA) (complete medium, CM).

\section{Antigen}

Mtb H37-Rv strain was kindly provided by the Mycobacteria Section of Instituto Nacional de Enfermedades Infecciosas, ANLIS, Dr C. G. Malbrán (Buenos Aires, Argentina). Mycobacterial strain H37Rv was grown on 7H11 agar (Difco Laboratories, Detroit, USA) at $37^{\circ} \mathrm{C}$ in $5 \% \mathrm{CO}_{2}$ air at mid-log phase. Mycobacteria were harvested, sonicated to disrupt the clumps, washed three times by centrifugation and resuspended in phosphate buffered saline (PBS) free of pyrogen at a concentration of $1 \times 10^{8}$ bacteria/ml. Bacteria were killed by heating at $80^{\circ} \mathrm{C}$ for $20 \mathrm{~min}$ and then aliquots of bacterial suspensions were stored at $-20^{\circ} \mathrm{C}$ until their use. This mycobacterial suspension contains soluble as well as particulate antigens.

\section{Effector cells for cytotoxicity assays}

Either recently purified PBMC, resuspended in CM with $10 \%$ DMSO $\left(4 \times 10^{6}\right.$ cells $\left./ \mathrm{ml}\right)$ and stored at $-80^{\circ} \mathrm{C}$ until their use (subsequently referred to as ex vivo effector cells), or PBMC $\left(2 \times 10^{6}\right.$ cells/ml) cultured in Falcon 2063 tubes (Becton Dickinson, Lincoln, $\mathrm{PK}, \mathrm{NJ}, \mathrm{USA}$ ) at $37^{\circ} \mathrm{C}$ in humidified $5 \% \mathrm{CO}_{2}$ atmosphere, in $\mathrm{CM}$ with or without $\mathrm{Mtb}\left(1 \times 10^{6} \mathrm{bacteria} / \mathrm{ml}\right)$ (cultured cells) were employed as effector cells in the cytotoxic assay. On day 6 , thawed ex vivo effector cells and cultured cells were washed three times with RPMI 1640, resuspended in CM $\left(2 \times 10^{6}\right.$ cells $\left./ \mathrm{ml}\right)$ and tested for cytotoxic activity. Studies were performed at a $40: 1 \mathrm{E} /$ $\mathrm{T}$ ratio, unless otherwise stated.

Depletion of $\mathrm{CD}^{+}$-lymphocytes from ex vivo effector cells Ex vivo effector cells from tuberculosis patients were thawed and depleted of $\mathrm{CD}^{+} \mathrm{T}$ cells by a magnetic method. Of these, $2 \times 10^{6}$ cells were incubated with anti-CD3 antibody (clone 1452C 11) during $30 \mathrm{~min}$ at $4^{\circ} \mathrm{C}$, after which they were incubated for $30 \mathrm{~min}$ with goat antimouse IgG-coated magnetic beads (Dynal Oslo, Norway) and non-rosetted cells were separated using a magnet.

\section{Isolation of $\mathrm{CD}^{+}, \mathrm{CD}^{+}$and $\gamma \delta \mathrm{T}$ lymphocytes from cultured $P B M C$}

$\mathrm{CD}^{+}$and $\mathrm{CD} 8^{+} \mathrm{T}$ cells were obtained by negative selection with magnetic beads (Dynal) from 6 day-cultured PBMC. For CD4 ${ }^{+}$ and $\mathrm{CD}^{+} \mathrm{T}$ cell enrichment, cells were treated with anti- $\gamma \delta \mathrm{TCR}$ (Pan $\gamma / \delta$, IgG1, clone Immun 510, Immunotech, Marseille, France) anti-CD56 (Leu-19, IgG1, clone MY31, Becton Dickinson, CA, USA) and anti-CD16 (Leu-11b, IgM, clone GO22, Becton Dickinson) monoclonal antibodies (MoAb), followed by goat 
antimouse IgG-coated beads. Anti-CD8 or anti-CD4-coated beads were used to enrich for $\mathrm{CD} 4^{+}$and $\mathrm{CD} 8^{+}$, respectively. For $\gamma \delta$ $\mathrm{T}$ cell enrichment, cells were treated with anti-CD16 followed by goat-antimouse IgG-coated beads and anti-CD4- plus anti-CD8coated beads. In all cases, cells were also depleted of B cells using anti-pan B-coated beads (Dynal). One cycle of treatment was sufficient for an effective depletion as assessed by flow cytometry. Purity was $90-95 \%$ in each case. Isolated $\mathrm{CD} 4^{+}, \mathrm{CD}^{+}$and $\gamma \delta \mathrm{T}$ cells were resuspended in $\mathrm{CM}$, ensuring that the proportion of each subset was the same as in total cultured PBMC in order to compare the lytic activity.

\section{Target cells}

Monocytes were allowed to adhere to the bottom of 24-well flatbottom Falcon plates by incubation of PBMC $\left(5 \times 10^{6} / \mathrm{ml}\right)$ for $2 \mathrm{~h}$ at $37^{\circ} \mathrm{C}$. After removing non-adherent cells, cells remaining in the plates $(10 \%$ of the original cell suspension) were incubated at $37^{\circ} \mathrm{C}$ in a humidified $5 \% \mathrm{CO}_{2}$ atmosphere for 6 days. For the cytotoxic assays, on day 5 of incubation, macrophages were pulsed with $M t b\left(1 \times 10^{6}\right.$ bacteria/ml). Macrophages kept under the same conditions but without addition of antigen were used as controls. On day 6 , plates were cooled for $2 \mathrm{~h}$ at $4{ }^{\circ} \mathrm{C}$ to facilitate the detachment of adherent cells by vigorous pipetting using icecold medium. These cells were washed and pellets of $5-7 \times 10^{5}$ cells were labelled with $100 \mu \mathrm{Ci}$ of $\mathrm{Na}_{2}{ }^{51} \mathrm{CrO}_{4}$ (New England Nuclear, Boston, MA, USA) by incubation for $1 \mathrm{~h}$ at $37^{\circ} \mathrm{C}$. The cells were then washed three times and resuspended in $\mathrm{CM}$ at $1 \times 10^{5}$ cells $/ \mathrm{ml}$.

\section{Cytotoxic assay}

Target cells, $4 \times 10^{3}$, were seeded into each well of 96-well microtitre plates (Corning, USA). Effector cells were added in triplicate at different effector to target cell ratios in $0.2 \mathrm{ml}$ final volume. The plates were centrifuged at $50 \mathrm{~g}$ for $5 \mathrm{~min}$ and incubated at $37^{\circ} \mathrm{C}$ in $5 \% \mathrm{CO}_{2}$ for $4 \mathrm{~h}$. After centrifugation at $200 \mathrm{~g}$ for $5 \mathrm{~min}$, the radioactivity of $100 \mu \mathrm{l}$ of supernatant and pellet from each well was measured in a gamma counter. Results were expressed as percentage of cytotoxicity $(\% \mathrm{Cx})$ :

$$
\% \mathrm{Cx}=\frac{\mathrm{cpm} \text { experimental }-\mathrm{cpm} \text { spontaneous release }}{\mathrm{cpm} \text { total }-\mathrm{cpm} \text { spontaneous release }} \times 100
$$

Spontaneous release is the radioactivity released from target cells incubated with $\mathrm{CM}$ alone, ranging from 8 to $15 \%$. In all cases, the cytotoxic assays performed with PBMC cultured in the absence of $M t b$ or with macrophages not pulsed with antigen rendered negligible cytotoxicity (0-6\%). Data presented in Tables 1-4 and Figs 1-4 were obtained by subtracting the percentage of cytotoxicity against non-antigen-pulsed macrophages from the experimental values determined using antigen-pulsed targets.

In order to analyse the nature of ex vivo effector cells, $1 \times 10^{6}$ PBMC were incubated with $10 \mu \mathrm{g} / \mathrm{ml}$ of anti-CD56 (Leu-19, Becton Dickinson), anti-CD16 (clone 3G8, IgG1, Immunotech) [26] or $1 \mu \mathrm{g} / \mathrm{ml}$ of anti-TCR $\gamma \delta$ (Pan $\gamma / \delta$, clone IMM 510, Immunotech) $\mathrm{MoAb}$. Target cells were incubated with $10 \mu \mathrm{g} / \mathrm{ml}$ of anticlass-I MHC (anti-HLA-ABC, IgG2 $\kappa$ (mouse), clone B9·12·1, Immunotech), anticlass-II MHC (anti-HLA-DR, IgG2a, clone L243, Becton Dickinson) or anti-CD1b (anti-CD1b, IgG2a, clone 4.A7·6, Immunotech) [27] MoAb. After 1 h-incubation at $37^{\circ} \mathrm{C}$, effector and target cells were washed twice and used in the cytotoxic assay. Isotype-matched non-relevant control antibodies for each $\mathrm{MoAb}$ employed were also tested and they had no significant effect on cytotoxicity.

On the other hand, to prevent the interaction of Fas and FasL expressed on ex vivo effector cells or $M t b$-induced $\mathrm{CD}^{+}$, $\mathrm{CD}^{+}$and $\gamma \delta \mathrm{T}$ cytotoxic effector cells, ${ }^{51} \mathrm{Cr}$-labelled antigenpulsed target macrophages were preincubated for $1 \mathrm{~h}$ with antihuman CD95 (Fas) MoAb (clone ANC95·1/5E2, IgG1, $2 \mu \mathrm{g} / \mathrm{ml}$, Ancell, Bayport, MN, USA) prior to the addition of the effector cells. According to Dieli et al. [24], antiperforin $\mathrm{MoAb}$ (antihuman perforin, clone $\gamma \mathrm{G} 9, \quad \operatorname{IgG} 2 \mathrm{~b}, 5 \mu \mathrm{g} / \mathrm{ml}$, Ancell) was added during the cytotoxic assay in order to block pore-forming perforin action. Isotype matched nonrelevant antibodies were also tested and no significant inhibition was observed.

\section{Immunofluorescence analysis}

Expression of $\mathrm{CD}_{16^{+}}, \mathrm{CD}_{56^{+}}$on $C D 3^{-}$and $\gamma \delta \mathrm{CD}^{+} \mathrm{T}$ cells. PBMC were incubated during $30 \mathrm{~min}$ at $4^{\circ} \mathrm{C}$ with FITC or PEconjugated MoAb specific for the human CD16 (Leu-11a-FITC or Leu-11c-PE, Becton Dickinson), CD56 (Leu 19-PE, Becton Dickinson), CD3 (CD3-Tri-Color, Caltag, Burlingame, CA, USA), anti- $\alpha \beta$ TCR (Pan $\alpha \beta$ TCR-FITC, Immunotech) or anti- $\gamma \delta$ TCR (Pan $\gamma / \delta$-FITC, Immunotech).

Expression of surface membrane FasL antigen on $\mathrm{CD}^{+}, \mathrm{CD} 8^{+}$ and $\gamma \delta T$ cells. Ex vivo effector cells, control and Mtb-stimulated PBMC were incubated with FITC-conjugated MoAb specific for the human CD4 (anti-CD4-FITC, Ancell), CD8 (anti-CD8-FITC, Ancell), $\gamma \delta$ TCR (Pan $\gamma / \delta$-, Immunotech) or CD95-Ligand antigen (anti-Fas-L-PE, Ancell) (30 min, $\left.4^{\circ} \mathrm{C}\right)$.

Expression of intracellular perforin. Either ex vivo effector cells or control and $M t b$ induced effector cells were incubated during $4 \mathrm{~h}$ with monensin ( $3 \mu \mathrm{M}$, Sigma, St Louis, MO, USA) at $37^{\circ} \mathrm{C}$ and were then incubated with anti-CD4, anti-CD 8 or anti$\gamma \delta$ TCR MoAb for $15 \mathrm{~min}$ at room temperature. Thereafter, the cells were fixed (Fix and Perm, Caltag) according to the manufacturer's instructions. Cells were then washed, suspended in PBS-FCS-azide and PE-antiperforin MoAb (Ancell) was added together with permeabilizing solution (Fix and Perm). Cells were incubated for $30 \mathrm{~min}$ at $4^{\circ} \mathrm{C}$ and washed once with PBSFCS-azide.

Expression of class-I and class-II MHC antigens on $\mathrm{CD} 14^{+}$ monocytes. Recently isolated as well as 6 days-cultured PBMC (with or without $M t b$ ) were incubated with anticlass-I (antiHLA-ABC-FITC, Immunotech) or anticlass-II (anti-HLA-DRFITC, Becton Dickinson) and anti-CD14 -PE (Immunotech) (30 min, $4^{\circ} \mathrm{C}$ ). Then, cells were washed and stained cells were analysed as mentioned above. FITC- or PE- labelled- isotype matched labelled non-relevant antibodies were also tested to evaluate non-specific staining. Results are expressed as percentage of positive cells or as mean of fluorescence intensity (MFI) or as the percentage of the mean of fluorescence intensity (MFI) observed in normal individuals (\% MFI).

\section{Statistics}

Comparisons of pre-TB, TB and N were performed using Student's $t$-test. Cytotoxicity values obtained from the different subsets of effector cells of each individual were compared using the Wilcoxon signed rank test. Individual $\mathrm{CD} 4^{+}, \mathrm{CD} 8^{+}$and $\gamma \delta$ CTL activity values were correlated employing the linear regression test. 
Table 1. Depletion of $\mathrm{CD}^{+}$cells inhibited the lysis of $M t b$-pulsed macrophages by ex vivo effector cells from patients with tuberculosis

$\%$ cytotoxicity, whole cells

Ex vivo effector

cells from

$1(\mathrm{M}-\mathrm{TB})$

2 (M-TB)

3 (M-TB)

4 (M-pre-TB)

5 (M-pre-TB)

6 (A-TB)

7 (A-TB)

8 (A-TB)

9 (A-TB)

10 (A-pre-TB)

10 (A-pre-TB)

11 (A-pre-TB)

\begin{tabular}{ll}
\hline Unpulsed & $M t b$-pulsed \\
macrophages & macrophages
\end{tabular}

$\%$ cytotoxicity, CD3-depleted

\begin{tabular}{ll}
\hline Unpulsed & $M t b$-pulsed \\
macrophages & macrophages
\end{tabular}

Ex vivo effector cells from patients with tuberculosis were depleted (CD3-depleted) or not (whole cells) of $\mathrm{CD}^{+}$cells by magnetic methods as described in Materials and methods. Then, both cell suspensions were tested for their cytotoxic ability to lyse unpulsed or Mtb-pulsed macrophages. Results are expressed as percentage of cytotoxicity and individual data are shown.

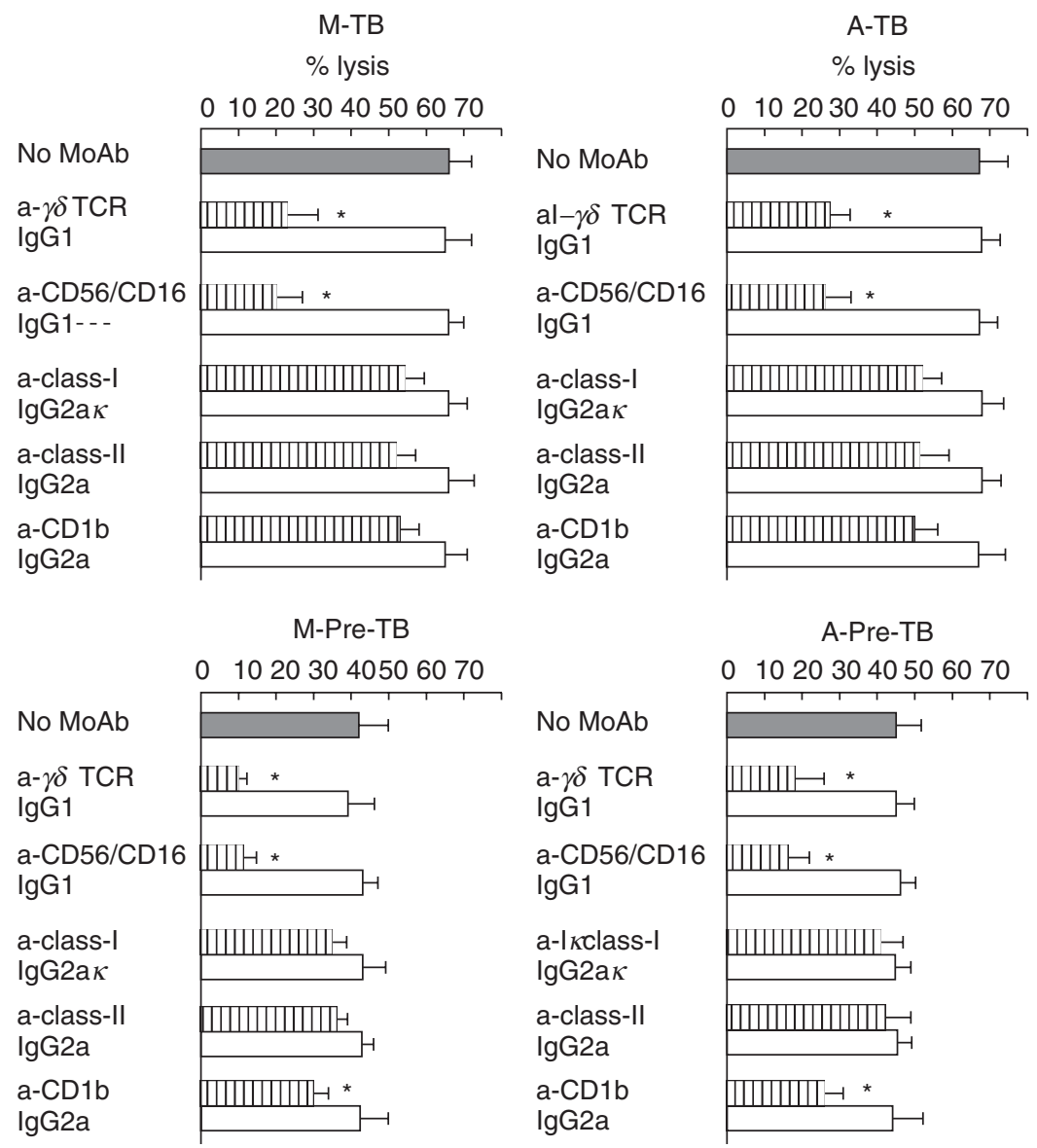

Fig. 1. Cytotoxic effector cells present in ex vivo cells from tuberculosis patients. Ex vivo cells from TB and pre-TB patients with $\mathrm{M}$ or $\mathrm{A}$ form of the disease were incubated with anti-CD56 and anti-CD16 or anti- $\gamma \delta$ TCR MoAb and target cells were treated with anti-MHC class-I, anti-MHC class II, anti-CD1b MoAb or isotype-matched non-relevant control antibodies before the cytotoxic assay, as described in Materials and methods. Results are expressed as percentage of cytotoxicity (mean \pm s.e.m.). Statistical differences between percentage cytotoxicity from untreated effector and target cells and from MoAb-treated effector or target cells: $*<0.05$. 
Table 2. Ex vivo effector cells from patients with tuberculosis lysed autologous and allogeneic $M t b$-pulsed macrophages

\begin{tabular}{|c|c|c|c|c|c|c|c|c|c|}
\hline \multirow{2}{*}{$\begin{array}{l}\text { Effector cells } \\
\text { from }\end{array}$} & \multicolumn{9}{|c|}{ Mtb-pulsed macrophages from (\% lysis) } \\
\hline & 1 & 2 & 3 & 4 & 5 & 6 & $\mathrm{~N} 1$ & $\mathrm{~N} 2$ & N3 \\
\hline 1. M-TB & 77 & - & 76 & - & - & - & 75 & 70 & - \\
\hline 2. M-TB & 84 & - & 80 & - & - & - & 80 & 83 & 85 \\
\hline 3. M-pre-TB & 69 & - & 71 & - & - & - & 72 & 68 & 70 \\
\hline 4. A-TB & - & 80 & 79 & - & - & - & 80 & 73 & 75 \\
\hline 5. A-TB & 71 & 68 & 71 & - & - & - & 70 & 66 & 67 \\
\hline 6. A-TB & - & - & - & 69 & 65 & 70 & - & - & 66 \\
\hline 7. A-pre-TB & - & - & - & 55 & 59 & - & - & 53 & 60 \\
\hline 8. A-pre-TB & - & - & - & 53 & - & 55 & - & - & 50 \\
\hline
\end{tabular}

Ex vivo effector cells from patients with tuberculosis (1-8) were tested for their lytic activity against autologous or allogeneic macrophages from patients with tuberculosis or normal individuals (N1, N2 or N3). Results are expressed as percentage of cytotoxicity and individual data are shown.
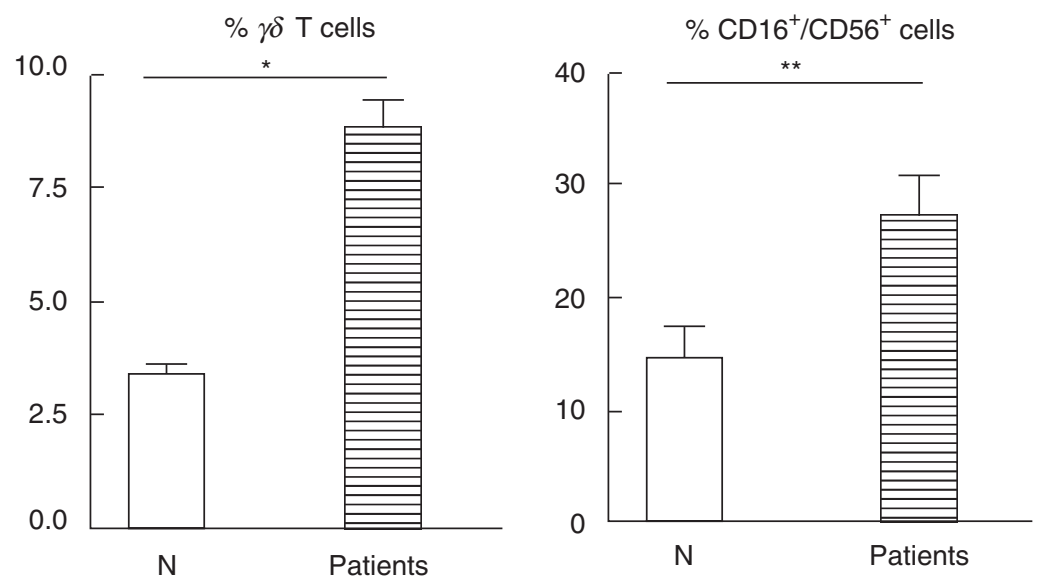

$\% \gamma \delta$ T cells bearing CD56

$\% \gamma \delta$ T cells bearing CD16
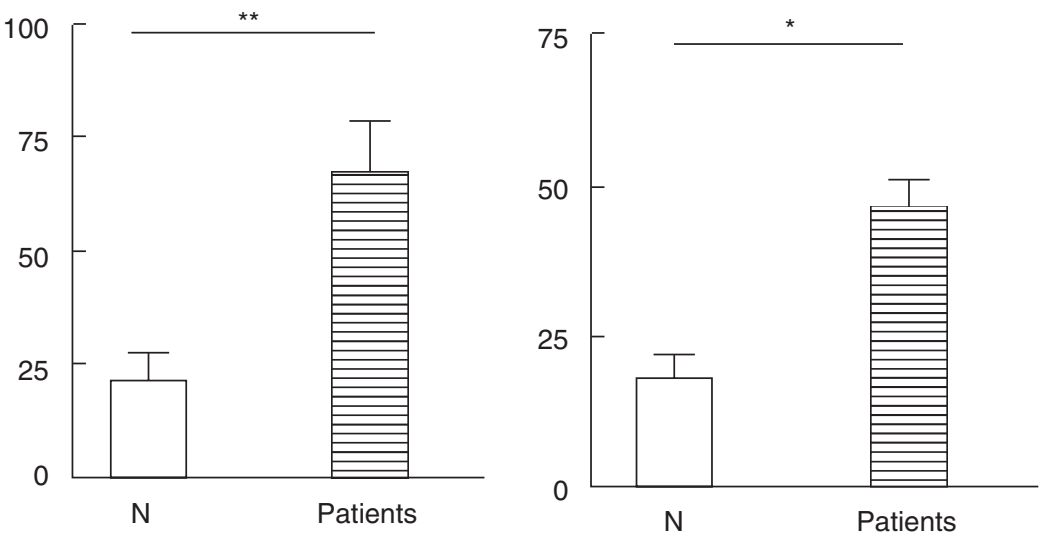

Fig. 2. Expression of $\mathrm{CD}_{1} 6^{+}, \mathrm{CD} 6^{+}$on $\mathrm{CD}^{-}$and $\gamma \delta \mathrm{CD}^{+} \mathrm{T}$ cells present on ex vivo cells. Ex vivo cells from 15 patients with tuberculosis and eight normal controls were tested for the presence of $\gamma \delta \mathrm{T}, \gamma \delta \mathrm{T} / \mathrm{CD} 56^{+}, \gamma \delta \mathrm{T} / \mathrm{CD} 16^{+}$and $\mathrm{CD} 3{ }^{-} \mathrm{CD} 16^{+} \mathrm{CD} 56^{+}$cells, as mentioned in Materials and methods. Results are expressed as mean \pm s.e.m. Statistical differences: $* P<0 \cdot 05, * * P<0 \cdot 01$. 
Table 3. $M t b$-induced $\gamma \delta$ T cells from patients with tuberculosis and normal controls lysed autologous and allogeneic macrophages

\begin{tabular}{|c|c|c|c|c|c|c|c|c|c|c|c|}
\hline \multirow{2}{*}{$\begin{array}{l}\gamma \delta \mathrm{T} \text { effector } \\
\text { cells from }\end{array}$} & \multicolumn{11}{|c|}{$M t b$-pulsed macrophages from (\% lysis) } \\
\hline & 1 & 2 & 3 & 4 & 5 & 6 & N1 & $\mathrm{N} 2$ & N3 & $\mathrm{N} 4$ & N5 \\
\hline 1. M-TB & 24 & 20 & 28 & - & - & - & 18 & 23 & 27 & - & - \\
\hline 2. M-TB & 26 & 26 & - & - & - & - & 17 & 20 & - & - & - \\
\hline 3. A-TB & 40 & - & 46 & - & - & - & 40 & 48 & - & - & - \\
\hline 4. A-TB & - & - & - & 48 & - & - & - & - & 47 & - & - \\
\hline 5. A-pre-TB & 16 & 23 & 20 & - & 39 & - & - & - & 31 & 28 & 32 \\
\hline 6. A-pre-TB & 20 & 24 & 21 & - & - & 35 & - & - & 32 & 29 & 26 \\
\hline $\mathrm{N} 1$ & 13 & - & - & - & - & - & 22 & 20 & 15 & - & - \\
\hline $\mathrm{N} 2$ & - & - & - & - & - & - & 25 & 24 & - & - & - \\
\hline N3 & - & - & - & 13 & 29 & 32 & 16 & - & 16 & 15 & 16 \\
\hline N4 & - & - & - & 10 & 13 & 10 & - & - & 12 & 13 & 14 \\
\hline N5 & - & - & - & 18 & 17 & 15 & - & - & 18 & 16 & 17 \\
\hline
\end{tabular}

$\gamma \delta \mathrm{T}$ cells isolated from $M t b$-stimulated PBMC from patients with tuberculosis (1-6) or normal individuals (N1 to N5) were tested for their lytic activity against autologous or allogeneic macrophages. Results are expressed as percentage of lysis and individual data are shown.

Table 4. Percentage of CD4, CD8 and $\gamma \delta$ T cells expressing Fas-Ligand or perforin

\begin{tabular}{|c|c|c|c|c|c|c|c|}
\hline & & \multicolumn{2}{|c|}{ Mild } & \multicolumn{2}{|c|}{ Advanced } & \multicolumn{2}{|c|}{ Normal } \\
\hline & & Control & $M t b$ & Control & $M t b$ & Control & $M t b$ \\
\hline \multirow[t]{9}{*}{ Fas-L } & $\mathrm{CD} 4^{+} \mathrm{T}$ cells & & & & & & \\
\hline & $\%(+)$ cells & $20 \pm 5$ & $28 \pm 5$ & $26 \pm 6$ & $25 \pm 7$ & $31 \pm 3$ & $33 \pm 4$ \\
\hline & MFI & $372 \pm 17$ & $328 \pm 56$ & $125 \pm 20$ & $148 \pm 56$ & $281 \pm 63$ & $394 \pm 37$ \\
\hline & $\mathrm{CD}^{+} \mathrm{T}$ cells & & & & & & \\
\hline & $\%(+)$ cells & $19 \pm 2$ & $21 \pm 2$ & $16 \pm 4$ & $15 \pm 2$ & $22 \pm 2$ & $15 \pm 2$ \\
\hline & MFI & $231 \pm 65$ & $202 \pm 13$ & $132 \pm 7$ & $128 \pm 24$ & $161 \pm 76$ & $131 \pm 26$ \\
\hline & $\gamma \delta \mathrm{T}$ cells & & & & & & \\
\hline & $\%(+)$ cells & $15 \pm 2$ & $31 \pm 2$ & $28 \pm 2$ & $43 \pm 9$ & $17 \pm 7$ & $28 \pm 2$ \\
\hline & MFI & $165 \pm 35$ & $155 \pm 18$ & $178 \pm 46$ & $164 \pm 5$ & $143 \pm 38$ & $243 \pm 53$ \\
\hline \multirow[t]{6}{*}{ Perforin } & $\mathrm{CD} 8^{+} \mathrm{T}$ cells & & & & & & \\
\hline & $\%(+)$ cells & $24 \pm 4$ & $23 \pm 4$ & $12 \pm 5$ & $18 \pm 6$ & $22 \pm 2$ & $24 \pm 1$ \\
\hline & MFI & $200 \pm 67$ & $247 \pm 52$ & $234 \pm 63$ & $216 \pm 75$ & $250 \pm 38$ & $283 \pm 81$ \\
\hline & $\gamma \delta \mathrm{T}$ cells & & & & & & \\
\hline & $\%(+)$ cells & $29 \pm 2$ & $27 \pm 6$ & $27 \pm 4$ & $32 \pm 8$ & $33 \pm 9$ & $33 \pm 7$ \\
\hline & MFI & $183 \pm 23$ & $202 \pm 15$ & $223 \pm 23$ & $203 \pm 58$ & $239 \pm 17$ & $217 \pm 33$ \\
\hline
\end{tabular}

$\mathrm{CD}^{+}, \mathrm{CD}^{+}$and $\gamma \delta \mathrm{T}$ cells expressing FasL or perforin, present in control and $M t b$-stimulated PBMC cultures from mild $(n=6)$ and advanced $(n=5)$ tuberculosis patients, and $\mathrm{N}$ controls $(n=6)$ were evaluated as described in Methods. Results are expressed as the percentage of FasL and perforin positive cells present in the $\mathrm{CD} 4^{+}, \mathrm{CD} 8^{+}$and $\gamma \delta \mathrm{T}$ cell populations; the mean of fluorescence intensity is also shown (MFI). No statistical differences were observed.

\section{RESULTS}

Lytic activity of ex vivo and Mtb-stimulated PBMC

The ability of ex vivo effector cells and 6-days cultured PBMC from patients with mild (M) and advanced (A) tuberculosis and normal individuals $(\mathrm{N})$ were tested for their ability to lyse autologous macrophages pulsed with $M t b$ at different E/T ratios. As shown in Fig. 5a, ex vivo effector cells from neither PPD $^{+}$nor $\mathrm{PPD}^{-} \mathrm{N}$ individuals lysed $M t b$-pulsed macrophages. In contrast, those cells from TB and pre-TB patients with $\mathrm{M}$ and A disease could lyse antigen-pulsed macrophages in a dose-dependent manner. A lower lytic activity was observed in ex vivo effector cells from pre-TB patients than in cells from $\mathrm{TB}$ at all $\mathrm{E} / \mathrm{T}$ ratios employed (Fig. 5a).
Development of antigen-specific effector cells (CTL) was induced by culture of PBMC with $M t b$ during 6 days. As shown in Fig. 5b, cytotoxic responses in $\mathrm{N}\left(\mathrm{PPD}^{+}\right.$and $\left.\mathrm{PPD}^{-}\right)$as well as in the four groups of patients were observed at different $\mathrm{E} / \mathrm{T}$ cell ratios. Both cultured and ex vivo effector cells from pre-TB patients had a lytic activity lower than that observed in cells from TB patients.

Characterization of ex vivo cytotoxic effector cells

Further experiments were performed in order to analyse the nature of the cytotoxic cells present in ex vivo effector cells. For this purpose, ex vivo effector or target cells were treated with $\mathrm{MoAb}$ prior to the cytotoxic assay. As shown in Fig. 1, lysis of 

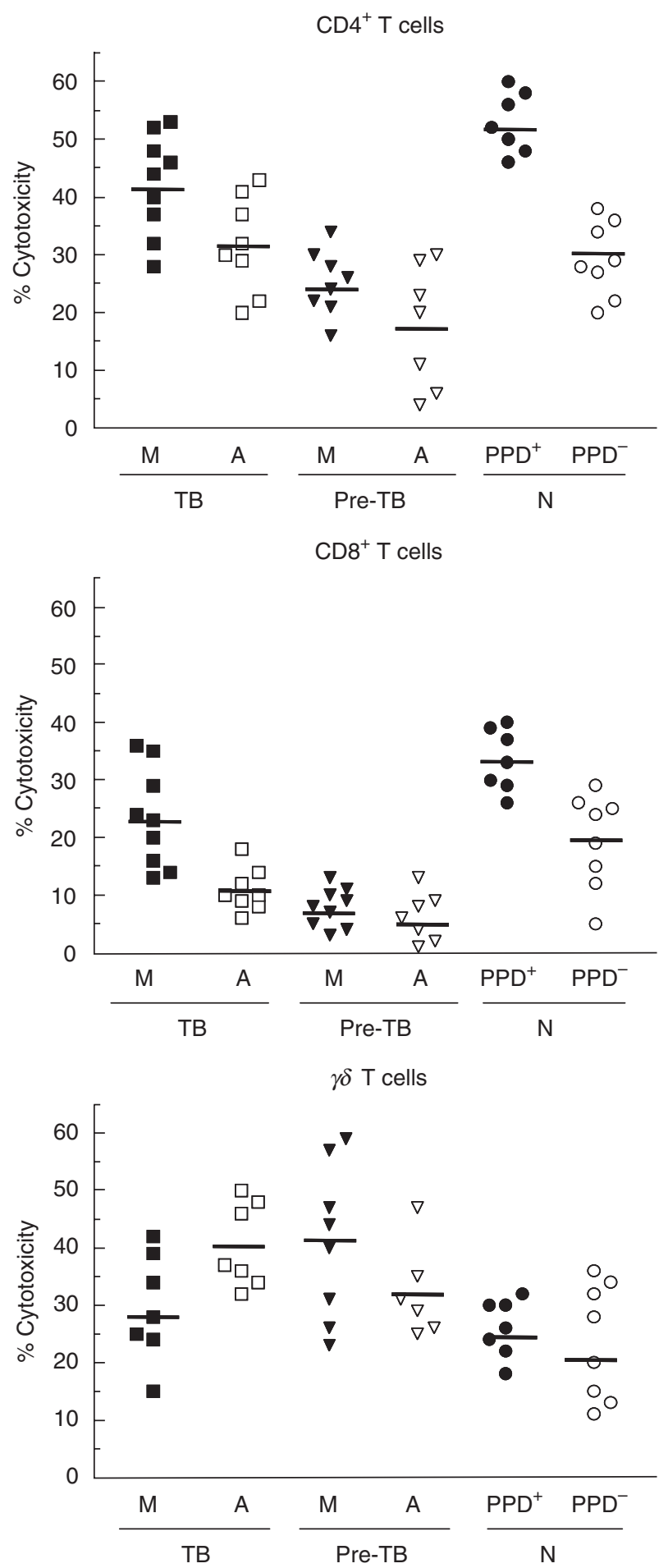

$M t b$-pulsed macrophages was inhibited markedly when the TCR $\gamma \delta$ was masked by treatment of ex vivo effector cells in the four groups of patients studied. An inhibition of lysis was also observed when effector cells were treated with a combination of anti-CD16 and anti-CD56 (anti-16/56) MoAb. Therefore, an involvement of TCR $\gamma \delta$, CD16 and CD56 molecules on the lysis of $M t b$-pulsed macrophages by ex vivo effector cells seems to be required. Conversely, lysis was not inhibited by blocking class I or class II antigens on target cells in all the groups studied. Isotype matched non-relevant control antibodies for each $\mathrm{MoAb}$
Fig. 3. $M t b$-induced $\mathrm{CD}^{+} \alpha \beta \mathrm{TCR}^{+}, \mathrm{CD}^{+} \alpha \beta \mathrm{TCR}^{+}$or $\gamma \delta \mathrm{TCR}^{+}$cytotoxic effector T cells: $\mathrm{CD} 4^{+}$and $\mathrm{CD} 8^{+}$expressing the $\alpha \beta$ TCR and $\mathrm{CD}^{-} \mathrm{CD} 8^{-}$ expressing the $\gamma \delta$ TCR receptor were obtained from 6-day cultured PBMC by negative selection with magnetic beads as described in Methods. Nineteen TB patients [nine with mild (M-TB, - $-\mathbf{-})$ and 10 advanced disease (A-TB, $\square-\square$ )], 15 pre-TB [five with mild (M-pre-TB, $\mathbf{\nabla}-\mathbf{\nabla}$ ) and 10 with advanced disease (A-pre-TB, $\nabla-\nabla$ ] patients, five PPD $^{+} \mathrm{N}(\bullet-\bullet)$ and eight $\mathrm{PPD}^{-} \mathrm{N}\left(\mathrm{O}_{-} \mathrm{O}\right)$ were studied. The enriched populations were tested for their lytic activity against $M t b$-pulsed macrophages in a 4-h cytotoxic assay at a $40: 1 \mathrm{E} / \mathrm{T}$ ratio. Results are expressed as percentage of cytotoxicity (individual data). Statistical differences: $\mathrm{CD} 4^{+} \mathrm{CTL}$ activity - patients versus $\mathrm{PPD}^{+} \mathrm{N}$ : M-TB, $P<0.05$, A-TB, M-pre-TB and A-pre-TB, $P<0 \cdot 002$; patients versus $\mathrm{PPD}^{-} \mathrm{N}$ : M-TB, $P<0.005$; patients versus $\mathrm{M}-\mathrm{TB}$ : A-TB, $P<0.05, \mathrm{M}$-pre-TB and A-pre-TB, $P<0.01 ; \mathrm{PPD}^{+} \mathrm{N}$ versus $\mathrm{PPD}^{-} \mathrm{N}$, $P<0 \cdot 002$. CD $8{ }^{+} \mathrm{CTL}$ activity - patients versus $\mathrm{PPD}^{+} \mathrm{N}: \mathrm{M}-\mathrm{TB}, P<0 \cdot 05 ; \mathrm{A}-$ TB, M-P and A-pre-TB, $P<0 \cdot 002$; patients versus PPD $^{-}$N: A-TB, $P<0 \cdot 05$, M-pre-TB and A-pre-TB, $P<0 \cdot 01$; patients versus $\mathrm{M}$-TB: A-TB, $P<0 \cdot 05$; M-pre-TB and A-pre-TB, $P<0 \cdot 01$; PPD $^{+} \mathrm{N}$ versus $\mathrm{PPD}^{-} \mathrm{N}, P<0 \cdot 05 . \gamma \delta$ CTL activity - patients versus $\mathrm{PPD}^{+} \mathrm{N}$ : M-pre-TB, $P<0 \cdot 05$; patients versus PPD $^{-} \mathrm{N}$ : A-TB and M-pre-TB, $P<0 \cdot 05$.

(a)

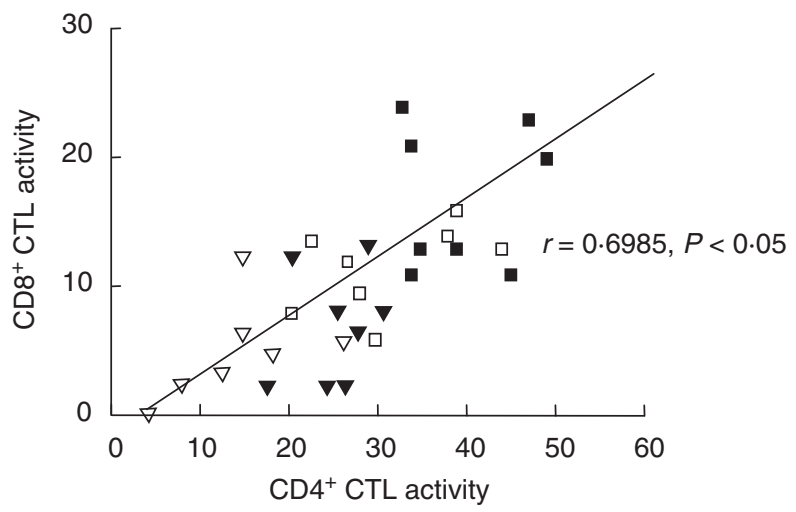

(b)

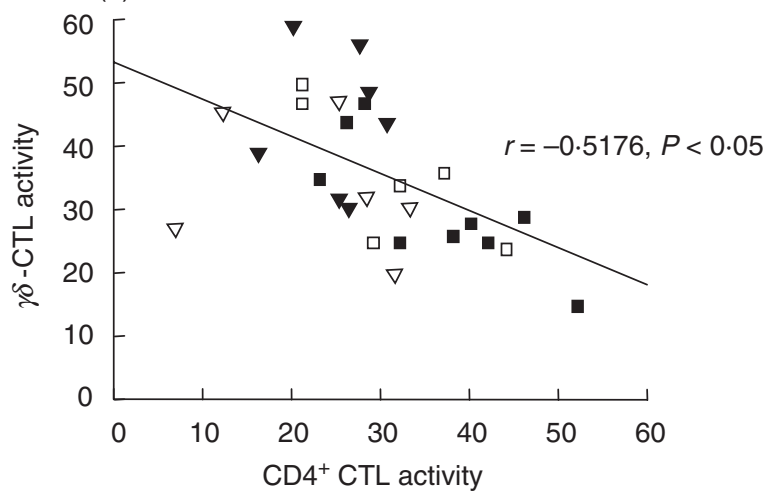

Fig. 4. Correlation between activities of CTL subpopulations in patients with tuberculosis. (a) $\mathrm{CD} 8^{+} \mathrm{CTL}$ and $\mathrm{CD} 4^{+} \mathrm{CTL}$; (b) $\gamma \delta \mathrm{CTL}$ and $\mathrm{CD} 4^{+} \mathrm{CTL}$. Individual $\mathrm{CD} 4^{+} \mathrm{CTL}, \mathrm{CD} 8^{+} \mathrm{CTL}$ and $\gamma \delta \mathrm{CTL}$ values (\% of cytotoxicity) from M-TB ( $-\square)$, A-TB ( $\square-\square)$, M-pre-TB ( $\mathbf{\nabla}-\mathbf{\nabla})$ and A-pre-TB $(\nabla-\nabla)$ patients were correlated employing the linear regression test. 
(a)

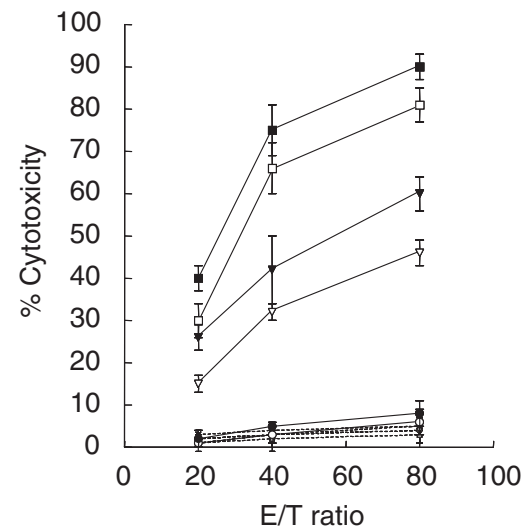

(b)

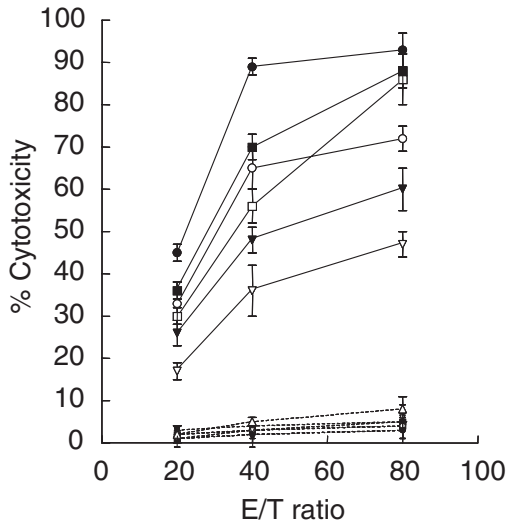

Fig. 5. Lytic activity of ex vivo and Mtb-stimulated PBMC. (a) Ex vivo effector cells from six patients without previous tuberculosis (TB) [three with M ( $\mathbf{\square}-\mathbf{\square})$ and three with A disease $(\square-\square)$ ], eight patients with a previous pulmonary tuberculosis (pre-TB) [four with $\mathrm{M}(\mathbf{\nabla}-$ $\boldsymbol{\nabla})$ and four with A disease $(\nabla-\nabla)]$ and 13 normal individuals $\left[(--)\right.$, five PPD $^{+} \mathrm{N}$ and $\left(\bigcirc_{-} \bigcirc\right)$, eight PPD $\left.^{-} \mathrm{N}\right]$ were tested for their lytic activity against autologous $M t b$-pulsed macrophages (-) and non-pulsed macrophages (---) in a 4-h cytotoxic assay, employing different effector to target cell ratios (E/T) as described in Materials and methods. Results are expressed as percentage of cytotoxicity. (b) PBMC from 12 TB [five with $\mathrm{M}(\boldsymbol{\square}-\boldsymbol{\square})$ and seven with A disease $\bigcirc-O)$ ], 10 pre-TB [four with $\mathrm{M}(\boldsymbol{\nabla}-\mathbf{\nabla})$ and six with A disease $(\nabla-\nabla)$ ] patients, five $\mathrm{PPD}^{+} \mathrm{N}(--\bullet)$ and eight $\mathrm{PPD}^{-} \mathrm{N}\left(\mathrm{O}_{-} \mathrm{O}\right) \mathrm{N}$ controls were stimulated during 6 days with $M t b$ and then tested for their lytic activity as mentioned above. Results are expressed as percentage of cytotoxicity.

employed were also tested and they had no significant effect on cytotoxicity. These results would suggest that cytotoxic effector cells from tuberculosis patients were non-MHC restricted, $\gamma \delta \mathrm{T}$ and/or $\mathrm{CD} 16^{+} / \mathrm{CD} 56^{+}$lymphocytes.

In order to delineate whether the lysis by ex vivo effector cells was dependent on LAK (lymphocyte activated killer cells) activity mediated by NK cells, ex vivo effector cells were depleted of $\mathrm{CD}^{+}$cells. As shown in Table 1, an important loss of the lytic activity was observed in $\mathrm{CD}^{+}$depleted cells, demonstrating that cytotoxic cells belonged to the $\mathrm{CD}^{+}$cells. Moreover, ex vivo effector cells from patients $(n=8)$ were not only able to lyse autologous but also allogeneic $M t b$-pulsed macrophages confirming their non-MHC restricted nature (Table 2). Furthermore, in patients with pre-TB, lysis of $M t b$-pulsed macrophages was inhibited when the CD1b antigen was blocked.

Taking into account that an in vitro expansion of $\gamma \delta \mathrm{T}$ cells by $M t b$ has been observed in PBMC from tuberculosis patients and $\mathrm{N} \mathrm{PPD}^{+}[8,9]$ and, due to the differences observed in the lytic activity of ex vivo effector cells from patients and $\mathrm{N}$, we undertook to evaluate the presence of lymphocyte subpopulations with lytic capacity such as $\gamma \delta \mathrm{T}$ and $\mathrm{NK}\left(\mathrm{CD} 16^{+} / \mathrm{CD} 56^{+}\right)$cells. As can be observed in Fig. 2 , the percentage of both $\gamma \delta \mathrm{T}(P<0 \cdot 05)$ and NK cells $(P<0.05)$ was increased in PBMC from tuberculosis patients compared to N. Since $\gamma \delta$ T cells bearing the CD56 antigen have been described as potent cytotoxic cells, we determined the percentage of $\gamma \delta \mathrm{T} / \mathrm{CD} 56^{+}$cells in ex vivo cells from tuberculosis patients which resulted higher than in $\mathrm{N}(P<0 \cdot 01)$. In addition, the percentage of $\gamma \delta$ T cells bearing CD16 was higher than that observed in $\mathrm{N}$ controls $(P<0 \cdot 05)$. Taking together all these results, we can assume that the lysis of $M t b$-pulsed macrophages observed in ex vivo cells from tuberculosis patients can be due to a high percentage of $\mathrm{CD}^{+} \gamma \delta \mathrm{T}$ cells bearing the CD56 and/or CD16 antigens.

Characterization of Mtb-induced cytotoxic cells

To determine the nature of effector cells involved in the Mtbinduced cytotoxic response, $\mathrm{CD} 4^{+}, \mathrm{CD}^{+}$and $\mathrm{CD} 4^{-} \mathrm{CD} 8^{-} \gamma \delta \mathrm{T}$ cells were isolated from control and $M t b$-stimulated 6-day cultures by negative selection. The involvement of the $\mathrm{T}$ cell subpopulations was quite different in patients and $\mathrm{PPD}^{+} \mathrm{N}$ or $\mathrm{PPD}^{-} \mathrm{N}$ controls. As shown in Fig. 3, significant differences in the development of antigen-specific $\mathrm{CD}^{+}-$and $\mathrm{CD}^{+}$-dependent cytotoxicity were detected between $\mathrm{PPD}^{+} \mathrm{N}$ and $\mathrm{PPD}^{-} \mathrm{N}$, with the highest $\mathrm{CD} 4^{+} \mathrm{CTL}$ and $\mathrm{CD}^{+} \mathrm{CTL}$ activity in $\mathrm{PPD}^{+} \mathrm{N}$. In tuberculosis patients, $M t b-$ induced $\mathrm{CD}^{+}$and $\mathrm{CD} 8^{+} \mathrm{CTL}$ activity diminished with the severity of the disease and with a previous overcome tuberculosis. CD $4^{+}$ and $\mathrm{CD}^{+}$cytotoxic activities in tuberculosis patients were lower compared to $\mathrm{PPD}^{+} \mathrm{N}$. While activity of $\mathrm{CD} 4^{+} \mathrm{CTL}$ from $\mathrm{M}$ and $\mathrm{A}-$ TB was higher or similar to that of cells from $\mathrm{PPD}^{-} \mathrm{N}$ it was diminished in pre-TB. Furthermore, only a negligible CD $8^{+} \mathrm{CTL}$ activity was observed in cells from A-TB and all pre-TB patients even when compared to $\mathrm{PPD}^{-} \mathrm{N}$ lytic activity. $\gamma \delta$-CTL activity was similar in $\mathrm{PPD}^{+}$and $\mathrm{PPD}^{-} \mathrm{N}$ controls while it was increased in cells from A-TB and M-pre-TB (Fig. 3). Besides, $M t b$-induced $\gamma \delta \mathrm{T}$ cells from patients with tuberculosis and $\mathrm{N}$ individuals were able to lyse either autologous or allogeneic $M t b$-pulsed macrophages demonstrating that lysis of target cells by $\gamma \delta$-CTL was non-MHC restricted (Table 3 ).

As can be seen in Fig. 4, $\mathrm{CD}^{+}$- and $\mathrm{CD} 4^{+}$-mediated cytotoxic activities correlated directly $(P<0 \cdot 05)$, while an indirect correlation was observed between $\gamma \delta$-CTL and $\mathrm{CD} 4{ }^{+} \mathrm{CTL}$ activities $(P<0.05)$ of PBMC from tuberculosis patients, suggesting that a defective MHC-restricted cytotoxic response could be compensated by a higher non-MHC restricted response.

\section{Expression of class-I and class-II MHC molecules on $\mathrm{CD}_{14}{ }^{+}$ monocytes}

Considering that the decrease of CTL activity might be due to a reduced expression of MHC molecules on the macrophages of tuberculosis patients, we analysed the expression of class-I and class-II molecules on $\mathrm{CD} 14^{+}$monocytes, which resulted similar on cells from nine TB and six pre-TB patients. Data are given as percentage of MFI observed in normal individuals, class-I, $\%$ MFI: TB $=95 \pm 15$, pre- 


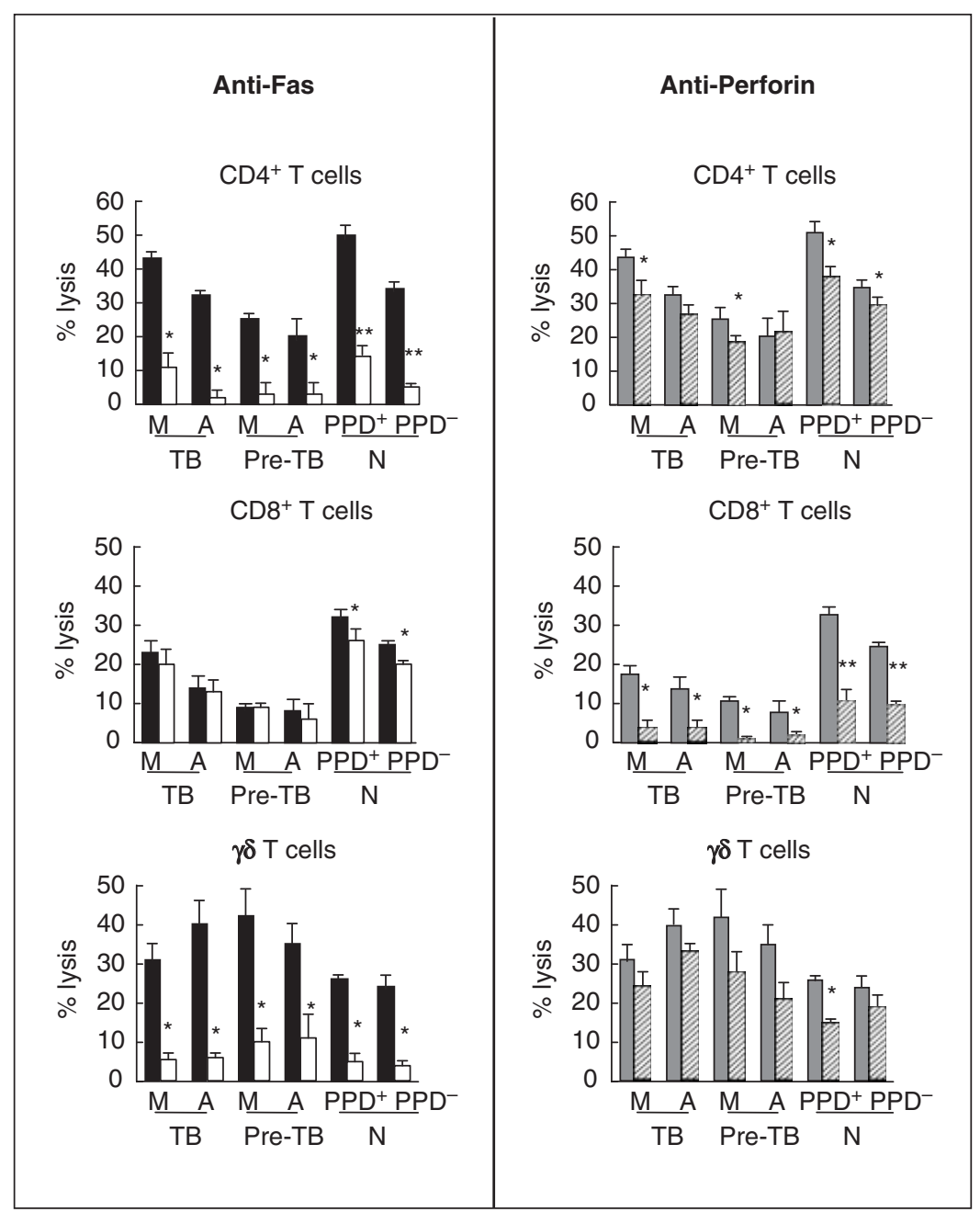

Fig. 6. Lytic mechanisms of $M t b$-induced $\mathrm{CD} 4^{+}, \mathrm{CD}^{+}$and $\gamma \delta \mathrm{T}$ effector cells: $M t b$-stimulated $\mathrm{CD} 4^{+}, \mathrm{CD} 8^{+}$and $\gamma \delta \mathrm{T}$ cells from nine $\mathrm{M}$-TB, eight A-TB, eight M-pre-TB and eight A-pre-TB patients and eight $\mathrm{PPD}^{+} \mathrm{N}$ and eight $\mathrm{PPD}^{-} \mathrm{N}$ controls (effector cells, E) were incubated during $4 \mathrm{~h}$ with (a) Mtb-pulsed macrophages (ם); (b) anti-Fas-treated and antigen-pulsed macrophages ( $\square$ ); or (c) antigen-pulsed macrophages in the presence of antiperforin $\operatorname{MoAb}(\mathbb{Z})$. Results are expressed as percentage of lysis $(\times \pm$ s.e.m. $)$. Statistical differences between percentage lysis from $(\mathrm{E}+$ anti-Fas treated antigen-pulsed target cells) or from $(\mathrm{E}+$ antigen-pulsed target cells + antiperforin) and percentage lysis from $(\mathrm{E}+$ antigen-pulsed target cells): $* P<0 \cdot 05, * * P<0 \cdot 01$

$\mathrm{TB}=99 \pm 12 ; \quad$ class-II, $\% \quad$ MFI: $\quad \mathrm{TB}=106 \pm 14, \quad$ pre$\mathrm{TB}=120 \pm 20$. Class-I expression was slightly enhanced in 6 day-cultured macrophages from patients (two A-TB and three pre-TB) without stimulus (control) $(\% \mathrm{MFI}=126 \pm 15)$ while no differences were observed in $M t b$-stimulated macrophages $(\% \mathrm{MFI}=90 \pm 12)$. Therefore, in tuberculosis patients the very low percentage of $\mathrm{CD}^{+} \mathrm{CTL}$ activity cannot be ascribed to a lower expression of class I molecules. On the other hand, class-II expression in control macrophages was slightly diminished ( $\% \mathrm{MFI}=84 \pm 15)$, while stimulation of patients' macrophages with $M t b$ reduced class-II expression ( $\% \quad M F I=58 \pm 13)$. This could partially explain the low $\mathrm{CD} 4^{+} \mathrm{CTL}$ activity observed in A-TB and pre-TB patients.

Lytic mechanisms used by ex vivo and Mtb-stimulated $C D 4^{+}$, $C D 8^{+}$and $\gamma \delta T$ cytotoxic effector cells

To investigate the lytic mechanisms used by ex vivo effector cells and $M t b$-induced cytotoxic $\mathrm{T}$ cells, assays were performed in the presence of neutralizing concentrations of anti-
Fas or antiperforin MoAb. In ex vivo effector cells the lytic activity from patients $(n=8, \%$ basal cytotoxicity $=83 \pm 4)$ was inhibited in the presence of anti-Fas $(43 \pm 5, \mathrm{p}<0.05)$ or antiperforin $(58 \pm 3, P<0.05)$. As shown in Fig. 6 , treatment of target cells with anti-Fas inhibited $M t b$-induced $\mathrm{CD}^{+}$and $\gamma \delta$ CTL activity in all groups. In $\mathrm{PPD}^{+}$as well as $\mathrm{PPD}^{-} \mathrm{N}$ controls, $M t b$-induced $\mathrm{CD}^{+} \mathrm{T}$ cell cytotoxicity was only partially inhibited by both anti-Fas and antiperforin'; however, this activity was abrogated in the presence of antiperforin in all patients. Lysis of $\mathrm{CD}^{+} \mathrm{T}$ cells from M-TB, M-pre-TB patients and all $\mathrm{N}$ controls, as well as $\gamma \delta$-CTL activity from $\mathrm{PPD}^{+} \mathrm{N}$, was slightly inhibited by antiperforin.

We then evaluated whether the impairment of CTL activity observed in patients could be attributed to a different percentage of effector cells expressing surface membrane FasL or intracellular perforin in patients and $\mathrm{N}$ controls. As shown in Table 4, a similar percentage of $\mathrm{CD}^{+}, \mathrm{CD}^{+}$and $\gamma \delta \mathrm{T}$ cells expressing FasL or perforin was observed in all groups. Although no significant differences could be found, in patients 
with the advanced form of the disease a decrease in the percentage of perforin positive $\mathrm{CD}^{+} \mathrm{T}$ cells and an increase in the percentage of Fas-L $\gamma \delta \mathrm{T}$ cells were observed. However, FasL expression on $M t b$-stimulated $\mathrm{CD}^{+}$and $\gamma \delta \mathrm{T}$ cells from patients and $\mathrm{N}$ controls was lower than that on $\mathrm{CD} 4^{+} \mathrm{T}$ cells. Besides, no differences in these parameters were observed in ex vivo effector cells (data not shown).

\section{DISCUSSION}

It has been demonstrated that lymphocytes from the lung of healthy $\mathrm{PPD}^{+}$individuals contain mycobacterial antigen-specific CTL precursors, which after being expanded can lyse alveolar or monocyte-derived macrophages, suggesting that CTL may have a role in protective immunity against $M t b$, both in the lung and in the periphery [6]. In the present report we have demonstrated that both ex vivo effector cells and $M t b$-stimulated PBMC from tuberculosis patients were able to lyse $M t b$-pulsed autologous macrophages, with differences according to the severity of the disease.

Our data show that monocyte-derived macrophages that present $M t b$ antigens can be lysed in a non-MHC restricted fashion by ex vivo effector cells from tuberculosis patients, demonstrating an in vivo activation of $\mathrm{CD}^{+} \gamma \delta \mathrm{T}$ cytotoxic effector cells. We also observed a high percentage of $\gamma \delta \mathrm{T}$ cells in PBMC from tuberculosis patients, which is consistent with reports by some authors [28,29] but differs from that of $\mathrm{Li}$ et al. [30], who described a similar frequency of $\gamma \delta$ T cells in patients and normal controls. In addition, we observed that more than half of the circulating $\gamma \delta \mathrm{T}$ cells from tuberculosis patients expressed the CD56 antigen. Although this antigen is usually detected in a low proportion of $\gamma \delta \mathrm{T}$ cells, an expansion of $\mathrm{CD}^{-}{ }^{-} \mathrm{CD} 8^{-}$as well as $\mathrm{CD} 8^{+}$ $\gamma \delta$ T cells bearing CD56 can be induced by the combination of IL12 and IL-2 [31,32]. The CD56 marker, which either alone or in combination with CD16 identifies the majority of mature NK cells, is able to modulate various $\gamma \delta$ T cell functions including cytotoxic activity and cytokine release [32]. Although the role of the CD56 molecule on lysis is not well understood, the fact that it was inhibited by the addition of anti-CD16 during the cytotoxic assay suggests that this NK receptor is also involved in the recognition or lysis of $M t b$-pulsed macrophages by $\gamma \delta \mathrm{T}$ lymphocytes. In this context, Mandelboin et al. [26] have demonstrated that the blockade of CD16 receptor inhibited the lysis of virus-infected and tumour cells by NK cells suggesting that CD16 is involved not only in the antibody-dependent cell cytotoxic activity (ADCC) but also in the direct NK lysis. Therefore, as demonstrated with other activation markers [33] cytokines produced during the inflammatory response to $M t b$ might enhance the CD56 expression on $\gamma \delta$ T cells, transforming them into more potent cytotoxic effector cells. Although down-regulation of CD1 molecule on macrophages by infection with live $M t b$ has been described [34], we observed that ex vivo cytotoxic effector cells from pre-TB recognized the CD1b molecule on target cells. Therefore, $\gamma \delta \mathrm{T}$ bearing $\mathrm{CD}_{5} 6^{+}$and/or $\mathrm{CD} 16^{+}$cells activated by lipids or glycolipid antigens might have arisen in vivo as a consequence of the mycobacterial disease. Although CD1 molecules have already been demonstrated for dendritic cells [14-16] perhaps, and as a late consequence of the previous disease, monocyte-derived macrophages that have not yet acquired the full characteristics of mature cells, might express CD1 on their surface. Hence, one may assume that under inflammatory conditions, monocytes from patients with tuberculosis and previous knowledge of the mycobacterial disease may have been preactivated by inflammatory cytokines [35] and/or by components of the bacilli [36] generating antigen presenting cells in a different stage of maturation that can be lysed by CD1-restricted $\gamma \delta$ T cells. Besides, these ex vivo cytotoxic effector cells, which might include NK effectors, kill the target cells through the Fas and perforin mechanisms.

It has been already demonstrated that antigen-specific $\mathrm{T}$ cells capable of lysing $M t b$-pulsed macrophages can be generated in PBMC from healthy $\mathrm{PPD}^{+}$donors upon $M t b$ stimulation $[6,8,19,37]$. However, the profile of cytotoxic $\mathrm{T}$ cells in PBMC from tuberculosis patients has not been studied in great detail. Our study confirms that both $\mathrm{CD}^{+}$and $\mathrm{CD} 8^{+}$cytotoxic cells were generated upon stimulation of $\mathrm{PBMC}$ from $\mathrm{PPD}^{+} \mathrm{N}$ with $M t b$. As we also included $\mathrm{PPD}^{-} \mathrm{N}$ donors, the higher capacity of $\mathrm{CD}^{+}$and $\mathrm{CD} 8^{+} \mathrm{CTL}$ to lyse macrophages presenting $\mathrm{Mtb}$ antigens observed in $\mathrm{PPD}^{+}$compared to $\mathrm{PPD}^{-} \mathrm{N}$ could be explained by the previous contact with the antigen. Conversely, in tuberculosis patients the decrease in $\mathrm{CD} 4^{+}$and $\mathrm{CD} 8^{+} \mathrm{CTL}$ activity can be associated to the severity of the disease and to an impairment to control the infection. In accordance with our results, a reduced cytotoxic $\mathrm{CD}^{+} \mathrm{T}$ lymphocyte activity was also obtained in tuberculosis patients compared to healthy $\mathrm{PPD}^{+}$controls in response to $M t b \mathrm{H} 37 \mathrm{Ra}$ [7]. The decrease in the lytic activity of $\mathrm{CD}^{+}$and $\mathrm{CD}^{+}$cytotoxic $\mathrm{T}$ cells could not be ascribed to differences in the expression of MHC class I and II molecules because only a low class-II expression was observed in Mtb-stimulated patients' macrophages [38], so that the weakened $\mathrm{CD}^{+}$and $\mathrm{CD} 8^{+} \mathrm{CTL}$ activities might be attributed to an inappropriate cytokine production by macrophages and $\mathrm{CD}^{+} \mathrm{T}$ cells, unable to provide help for $\mathrm{CD}^{+} \mathrm{CTL}$ development [39]. As a result, the faulty $\mathrm{CD}^{+}$cytotoxicity correlated with the progressive loss of $\mathrm{CD} 8^{+} \mathrm{CTL}$ activity. We have also demonstrated that $\gamma \delta \mathrm{CTL}$ were generated in $M t b$-stimulated PBMC from $\mathrm{PPD}^{+}$and $\mathrm{PPD}^{-} \mathrm{N}$ controls suggesting that these cells, involved in early defense mechanisms against $M t b$ until the adaptive response is mounted, have the capacity to recognize and respond to molecules on antigenpresenting cells even without a previous exposure to the mycobacteria. As described by Kumararatne et al. [37], in cell lines from tuberculosis patients, with the severity of pulmonary involvement the main CTL induced by $M t b$ are non-MHC restricted, but we identified this type of CTL as belonging to the $\mathrm{CD}^{-} \mathrm{CD}^{-} \gamma \delta \mathrm{T}$ phenotype. The higher the non-MHC restricted lytic activity, the bigger the loss of $\mathrm{CD} 4^{+}$and $\mathrm{CD} 8^{+} \mathrm{CTL}$ activity, suggesting that $\gamma \delta \mathrm{T}$ cytotoxicity could be a compensatory lytic mechanism in tuberculosis patients.

Published data, mainly from studies with clones or cell lines from healthy $\mathrm{PPD}^{+}$donors, are contradictory on whether the Fas and perforin pathways are involved in the restriction of $\mathrm{Mtb}$ growth [19,20,40-42]. As a similar expression of FasL and perforin in $\mathrm{CD}^{+}, \mathrm{CD}^{+}$and $\gamma \delta \mathrm{T}$ cells was observed in patients and normal controls, we assumed that CTL from all individuals might be able to use both lytic pathways. Our results concerning the death of target cells induced by $\mathrm{CD} 4^{+} \mathrm{CTL}$ from $\mathrm{PPD}^{+}$and $\mathrm{PPD}^{-} \mathrm{N}$ are in accordance with recent publications [19] where lysis by the two mechanisms was observed, even though in tuberculosis patients it was mediated mainly by the induction of apoptosis. Although the perforin pathway was employed by $\mathrm{CD} 8^{+} \mathrm{CTL}$ from tuberculosis patients and $\mathrm{N}$ controls, we have demonstrated a loss in the activity of these effector cells in most of the patients studied with a reduction in the expression of perforin in $\mathrm{CD}^{+}$cells observed in 
the advanced form of the disease. Therefore, we can speculate that other granule proteins such as granzyme and granulysin, responsible for the reduction in $M t b$ viability [20,21], are absent in $\mathrm{CD}^{+}$CTL from tuberculosis patients. According to previous studies $[24,40,41]$, we also found that $\mathrm{CD}^{-} \mathrm{CD} 8^{-} \gamma \delta \mathrm{CTL}$ from healthy $\mathrm{PPD}^{+}$controls use both lytic pathways to lyse $M t b$-pulsed macrophages. However our results, obtained with $\mathrm{T}$ cells derived from tuberculosis patients, suggest that lysis of the infected macrophages by $\mathrm{CD}^{-}{ }^{-} \mathrm{CD} 8^{-} \gamma \delta \mathrm{CTL}$, mediated by the Fas-FasL pathway, may only prevent the spread of $M t b$ infection without killing Mtb [20].

In conclusion, our results show that during a tuberculosis infection the in vivo activation of $\mathrm{CD}^{+} \gamma \delta$ T cell-bearing $\mathrm{CD} 56^{+}$ and/or CD16 molecules is responsible for the lysis of $M t b$-pulsed macrophages in a non-MHC restricted manner. Taking into account that human tuberculosis increases the homing capacities of peripheral blood $\gamma \delta$ T cells [33] we can infer that these cells, once migrated to the lung, could mediate the lysis of macrophages through mechanisms of apoptosis, suggesting that this type of lysis might control the inflammation avoiding tissue damage in an environment with a high number of mycobacteria. Furthermore, once the disease is installed, the first evidence observed in vitro is the loss of $\mathrm{CD} 8^{+} \mathrm{CTL}$ activity which together with an abrogation of $\mathrm{CD}^{+}$lytic activity and a high contribution of non-MHC restricted cytotoxic activity suggest that shifts in the CTL response and the cytolytic mechanisms take place as the pulmonary involvement becomes more severe. Hence, we can infer that the ability to generate an antigen specific cytotoxic response in tuberculosis patients is determined by an interplay of several factors such as cytokines released during the inflammatory response and/or different mycobacterial antigens available as infection progresses. Our results, obtained in patients who had previously overcome tuberculosis, suggests strongly that non-MHC restricted lysis mediated by $\mathrm{CD} 4^{-} \mathrm{CD} 8^{-} \gamma \delta \mathrm{CTL}$ induced by $M t b$ antigens is developed in an attempt to destroy the infected macrophages with a low spreading of the bacilli, avoiding the inflammatory process and extensive tissue damage.

\section{ACKNOWLEDGEMENTS}

We thank Dr Lucía Barrera for kindly providing the H37-Rv strain. We also thank the medical staff of División Tisioneumonología of Hospital F.J. Muñiz, for their great help in providing clinical samples from patients with tuberculosis. This work was supported by grants from the Consejo Nacional de Investigaciones Científicas y Técnicas (CONICET, PIP 0711/98), Agencia Nacional de Promoción Científica y Tecnológica (ANPCyT, 0504816)

\section{REFERENCES}

1 Flynn J, Chan J. Immunology of tuberculosis. Ann Rev Immunol 2001; 19:93-129.

2 Fazal N, Lammas DA, Rahelu M, Pithie AD, Gaston JS, Kumararatne DS. Lysis of human macrophages by cytolytic $\mathrm{CD} 4^{+} \mathrm{T}$ cells fails to affect survival of intracellular Mycobacterium bovis bacillus CalmetteGuerin (BCG). Clin Exp Immunol 1995; 99:82-9.

3 Pithie AD, Lammas DA, Fazel $\mathrm{N}$ et al. $\mathrm{CD}^{+}$cytolytic $\mathrm{T}$ cells can destroy autologous and MHC-matched macrophages but fail to kill intracellular Mycobacterium bovis-BCG. FEMS Immunol Med Microbiol 1995; 11:145-54.

4 Flynn JL, Goldstein MM, Triebold KJ, Koller B, Bloom BR. Major histocompatibility class I restricted $\mathrm{T}$ cells are required for resistance to
Mycobacterium tuberculosis infection. Proc Natl Acad Sci USA 1992; 89:12013-7.

5 Orme I, Miller E, Roberts A et al. T lymphocytes mediating protection and cellular cytolysis during the course of Mycobacterium tuberculosis infection. Evidence for different kinetics and recognition of a wide spectrum of protein antigens. J Immunol 1992; 148:189-96.

6 Tan JS, Canaday DH, Boom WH, Balaji KN, Schwander SK. Human alveolar T lymphocyte response to Mycobacterium tuberculosis. Role for $\mathrm{CD}^{+}$and $\mathrm{CD} 8^{+}$cytotoxic $\mathrm{T}$ cells and relative resistance of alveolar macrophages to lysis. J Immunol 1997; 159:290-7.

7 Smith SM, Klein MR, Mallin AS et al. Human $\mathrm{CD}^{+} \mathrm{T}$ cells specific for Mycobacterium tuberculosis secreted antigens in tuberculosis patients and healthy BCG-vaccinated controls in the Gambia. Infect Immun 2000; 68:7144-8.

8 Havlir DV, Ellner JJ, Chervenak KA, Boom WH. Selective expansion of human gamma delta T cells by monocytes infected with live Mycobacterium tuberculosis. J Clin Invest 1991; 87:729-33.

9 Kabelitz D, Bender A, Schondelmaier S, Schoel B, Kaufmann SHE. A large fraction of human peripheral blood $\gamma / \delta \mathrm{T}$ cells is activated by Mycobacterium tuberculosis but not by its $65-\mathrm{kD}$ heat shock protein. J Exp Med 1990; 171:667-79.

10 Tsukaguchi K, Balaji KN, Boom WH. $\mathrm{CD}^{+} \alpha \beta \mathrm{T}$ cell and $\gamma \delta \mathrm{T}$ cell responses to Mycobacterium tuberculosis: similarities and differences in antigen recognition, cytotoxic effector function and cytokine production. J Immunol 1995; 154:1786-96.

11 Schoel B, Gulle H, Kaufmann SHE. Heterogeneity of the repertoire of $\mathrm{T}$ cells of tuberculosis patients and healthy contacts to Mycobacterium tuberculosis antigens separated by high-resolution techniques. Infect Immun 1992; 60:1717-20.

12 Constant P, Davodeau F, Peyrat MA et al. Stimulation of $\gamma \delta$ T cells by nonpeptidic mycobacterial ligands. Science 1994; 264:267-70.

13 Tanaka Y, Morita C, Tanaka Y, Nieves E, Brenner MB, Bloom BR. Natural and synthetic nonpeptide ligands for human $\gamma \delta$ T cells. Nature 1995; 375:115-8.

14 Melian A, Beckman EM, Porcelli SA, Brenner MB. Antigen presentation by CD1 and MHC-encoded class I-like molecules. Curr Opin Immunol 1996; 8:82-6.

15 Porcelli SA, Modlin RL. The CD1 system. antigen-presenting molecules for T cell recognition of lipids and glycolipids. Annu Rev Immunol 1999; 17:297-29.

16 Matsuda JL, Kronenberg M. Presentation of self and microbial lipids by CD1 molecules. Curr Op Immunol 2001; 13:19-25.

17 Kägi D, Vignaux F, Ledermann B et al. Fas and perforin pathways as major mechanisms of T cell-mediated cytotoxicity. Science 1994b; 265:528-31.

18 Lewinsohn D, Bement T, Xu L et al. Human purified protein derivative-specific $\mathrm{CD}^{+}$cells use both CD95-dependent and CD95-independent cytolytic mechanisms. J Immunol 1998; 160:2374-9.

19 Canaday D, Wilkinson R, Li Q, Harding C, Silver R, Boom WH. $\mathrm{CD}^{+}$and $\mathrm{CD}^{+} \mathrm{T}$ cells kill intracellular M. tuberculosis by a perforin and Fas/Fas ligand-independent mechanism. J Immunol 2001; 167:2734-42.

20 Stenger S, Mazzaccaro R, Uyemura K et al. Differential effects of cytolytic T cell subsets on intracellular infection. Science 1997; 276:1684-7.

21 Stenger S, Hanson D, Teitelbaum R et al. An antimicrobial activity of cytolytic T cells mediated by granulysin. Science 1998; 282:121-5.

22 Koizumi H, Liu CC, Zheng LM et al. Expression of perforin and serine esterases by human $\gamma \delta$ T cells. J Exp Med 1991; 173:499-02.

23 Dieli F, Troye-Blomberg M, Ivanyi J et al. Granulysin-dependent killing of intracellular and extracellular Mycobacterium tuberculosis by $\mathrm{V} \gamma 9 / \mathrm{V} \delta 2 \mathrm{~T}$ lymphocytes. J Infect Dis 2001; 184:1082-5.

24 Dieli F, Troye-Blomberg M, Ivanyi J et al. V $\gamma 9 / \mathrm{V} \delta 2 \mathrm{~T}$ lymphocytes reduce the viability of intracellular Mycobacterium tuberculosis. Eur J Immunol 2000; 30:1512-9.

25 Boyum A. Isolation of mononuclear cells and granulocytes from human blood. Scand J Clin Invest 1968; 97:77-89. 
26 Mandelboim O, Malik P, Davis D, Ho Ch, Boyson J, Strominger JL. Human CD16 as a lysis receptor mediating direct natural killer cell cytotoxicity. Proc Natl Acad Sci USA 1998; 96:5640-4.

27 Ulanova M, Tarkovski A, Hahn-Zoric M, Hanson A. Participation of CD1 molecules in the presentation of bacterial antigens in humans. Scand J Immunol 1999; 50:387-93.

28 Ito M, Kojiro N, Ikeda T, Ito T, Funada J, Kokubu T. Increased proportions of peripheral blood $\gamma \delta \mathrm{T}$ cells in patients with pulmonary tuberculosis. Chest 1992; 102:195-7.

29 Barnes PF, Grisso CL, Abrams JS, Band H, Rea TH, Modlin RL. $\gamma \delta$ T lymphocytes in human tuberculosis. J Infect Dis 1992; 165:506-12.

$30 \mathrm{Li} \mathrm{B}$, Rossman MD, Imir T et al. Disease-specific changes in $\gamma \delta \mathrm{T}$ cells repertoire and function in patients with pulmonary tuberculosis. $\mathbf{J}$ Immunol 1996; 157:4222-9.

31 Battistini L, Borsellino G, Sawicki G et al. Phenotypic and cytokine analysis of human peripheral blood $\gamma \delta \mathrm{T}$ cells expressing NK cell receptors. J Immunol 1997; 159:3723-30.

32 Satoh M, Seki S, Hashimoto W et al. Cytotoxic $\gamma \delta$ or $\alpha \beta$ T cells with a natural killer cell marker, CD56, induced from human peripheral blood lymphocytes by a combination of IL-12 and IL-2. J Immunol 1996; 157:3886-92.

33 Behr-Perst S, Munk M, Schaberg T, Ulrich T, Shulz RJ, Kaufmann SHE. Phenotypically activated $\gamma \delta \mathrm{T}$ lymphocytes in the peripheral blood of patients with tuberculosis. J Infect Dis 1999; 180:144-8.

34 Stenger SK, Niazi R, Modlin RL. Down-regulation of CD1 expression on antigen-presenting cells by infection with Mycobacterium tuberculosis. J Immunol 1998; 161:3582-8.

35 Dlugovitzky D, Bay ML, Rateni L et al. In vitro synthesis of IFN $\gamma$, interleukin- 4 , transforming growth factor- $\beta$ and interleukin- $1 \beta$ by peripheral blood mononuclear cells from tuberculosis patients: relationship with the severity of pulmonary involvement. Scand J Immunol 1999; 49:210-7.

36 Tsuji S, Matsumoto M, Takeuchi $\mathrm{O}$ et al. Maturation of human dendritic cells by cell wall skeleton of Mycobacterium bovis CalmetteGuerin: involvement of toll-like receptors. Infect Immun 2000; 68:6883-90.

37 Kumararatne D, Pithie AS, Drysdale P et al. Specific lysis of mycobacterial antigen bearing macrophages by class-II MHC-restricted polyclonal $\mathrm{T}$ cell lines in healthy donors or patients with tuberculosis. Clin Exp Immunol 1990; 80:314-23.

38 Hamma Z, Gabathuler R, Jeffries WA, de Jong G, Reiner NE. Attenuation of HLA-DR expression by mononuclear phagocytes infected by Mycobacterium tuberculosis is related to intracellular sequestration of immature Class II heterodimers. J Immunol 1998; 161:4882-93.

39 Serbina N, Lazarevic V, Flynn J. CD4 ${ }^{+} \mathrm{T}$ cells are required for the development of cytotoxic $\mathrm{CD}^{+} \mathrm{T}$ cells during Mycobacterium tuberculosis infection. J Immunol 2001; 167:6991-00.

40 Passmore JS, Glashoff RH, Lukey PT, Ress SR. Granule-dependent cytolysis of Mycobacterium tuberculosis-infected macrophages by human $\gamma \delta^{+} \mathrm{T}$ cells has no effect on intracellular mycobacterial viability. Clin Exp Immunol 2001; 126:76-83.

41 Thoma-Uszynski S, Stenger S, Modlin RL. CTL-mediated killing of intracellular Mycobacterium tuberculosis is independent of target cell nuclear apoptosis. J Immunol 2000; 165:5773-9.

42 Oddo M, Renno T, Attinger A, Bakker T, MacDonald R, Meylan PR. Fas ligand-induced apoptosis of infected human macrophages reduces the viability of intracellular Mycobacterium tuberculosis. J Immunol 1998; 160:5448-54. 